\title{
Hikmet Temel Akarsu'nun Çocuğa Yönelik Eserlerindeki Fantastik Karakterlerin Kişilik Özelliklerinin Analizi ${ }^{a}$
}

\author{
Mehmet Fidan ${ }^{\mathrm{b}, \mathrm{c}}$, Osman Gündüz ${ }^{\mathrm{d}}$
}

Anahtar Kelimeler

Özet

Kaçış edebiyatı olarak da nitelendirilen fantastik edebiyat anlatııısına sağladığı sınırsız hayal gücü ve kendini ifade edebilme imkânları ile yazarların tercih ettiği bir yazın türü olarak öne çıkmaktadır. Özellikle son dönemde bazı fantastik eserlerin sinemaya uyarlanması ve bu filmlerin yüksek izleyici sayısına ulaşması onlara kaynaklık eden eserlere karşı da okuyucunun ilgi göstermesine imkân sağlamıştır. Bu durum dolaylı olarak diğer fantastik eserlere de olumlu yönde etki etmiştir. Bu türden fantastik ögeler taşıyan eserlerin çocuklar, gençler için ilgi çekici olması eğitsel açıdan bir fırsat olarak görülmüş ve bu eserler eğitsel amaçlı da kullanılmaya başlanmıştır. Hikmet Temel Akarsu'nun çocuğa yönelik eserlerinde fantastik ögelerin eğitsel amaçlar doğrultusunda kullanıldığı görülmektedir. Bu araştırmanın amacı Hikmet Temel Akarsu'nun çocuğa yönelik eserlerindeki fantastik karakterlerin kişilik özelliklerinin belirlenmesidir. Araştırma sürecinde nitel yöntemlerden betimsel analiz metodu kullanılmıştır. Yazarın çocuğa yönelik eserlerindeki fantastik karakterlerin kişilik özellikleri olarak çevrecilik, iyilikseverlik ve doğruluk tespit edilmiştir.

Anahtar Kelim
Fantastik Ede
Hikmet Temel Ak
Kişilik Özell
Makale Hakk
Geliş Tarihi: 30.10
Kabul Tarihi: 13.03
Doi: 10.18026/cbayarsos.47

racters in Children's

Abstract

Fantastic literature, which is also known as escape literature, stands out as a type of literature preferred by the authors with the unlimited imagination and self-expression opportunities it provides to its narrator. Especially in the recent period, the adaptation of some fantastic works to the cinema and the fact that these films have reached a high number of viewers have enabled the reader to show interest to the works that source them. This situation indirectly had a positive effect on other fantastic literature works. The fact that the works carrying such fantastic elements are interesting for children and young people has been seen as an educational opportunity and these works have also been used for educational purposes. In Hikmet Temel Akarsu's works aimed at children, it is seen that fantastic elements are used for educational purposes. The aim of this study is to determine the personality characteristics of the fantastic characters in Hikmet Temel Akarsu's works aimed at the child. In the research process, descriptive analysis method was used. The personality characteristics of the fantastic characters in the author's works directed towards the child were determined as environmentalism, benevolence and accuracy.
Keywords

Fantasy Literature

Hikmet Temel Akarsu

Personality Characteristics

\footnotetext{
a Bu makale "Hikmet Temel Akarsu'nun Eserlerindeki Fantastik Ögeler ve Eğitim Odaklı Değerler" isimli doktora tezinden yararlanılarak üretilmiştir.

b İletişim Yazarı: fidanm3838@gmail.com

c Dr. Öğr. Üyesi, Aksaray Üniversitesi Eğitim Fakültesi Türkçe ve Sosyal Bilimler Eğitimi Bölümü, ORCID: 0000-0002-9347-2992

d Prof. Dr., Bayburt Üniversitesi İnsan ve Toplum Bilimleri Fakültesi Türk Dili ve Edebiyatı Bölümü
} 


\section{Giriş}

Hayali olan, olağanüstü gibi nitelendirmelerle anılan fantastik edebiyat uzun bir süreden beri edebiyat dünyasında tartışmaların odak noktasında bulunmuştur. Bu tartışmanın temelinde fantastik edebiyatın sınırlarının ve niteliklerinin belirlenmesi gerekliliği yer almaktadır. Korkmaz'ın (2013, s.13) "parçalanmalar, paylaşımlar ve yeni oluşumlar çağı" olarak nitelendirdiği 19. yüzyıl, birçok açıdan bilimsel gelişmelere etki eden rasyonalist düşünce yapısının edebiyat dünyasında da tesirini gösterdiği bir dönemdir. Türk edebiyatında ise Şinasi, Namık Kemal, Sadullah Paşa gibi aydınlar bu düşünce yapısının yani modernliğin ilk temsilcileri arasında görülmektedir (Korkmaz, 2013, s.30-37). Bu durum fantastik nitelikler taşıyan eserlere yönelik bir ön yargının oluşmasına sebep olmuştur. Özlük (2011, s.11) bu türden eserlerin uzun yıllar boyunca gerçeklik algısı sebebiyle edebi nitelikten yoksun olarak görüldügünü belirtir. Belirtildiği üzere özellikle Tanzimat döneminden itibaren dönem yazarlarının genelde realist tarzda metinler kaleme aldıkları görülmüştür. Ancak bu alanda çok fazla olmasa da bazı örnek eserler yer almaktadır. Birçok araştırmacının ortak kanı olarak kabul ettiği dünya edebiyatının ilk fantastik metinlerinden olan Binbir Gece Masalları taşıdığı nitelikler açısından tam bir fantastik metin sayılmasa da Tanpınar'ın (2013, s.45) "tabiatüstü tesadüfler" olarak nitelendirdiği fantastik ögeleri içerisinde barındırmaktadır. Todorov (2012, s.33), Batı edebiyatının ilk fantastik eseri olarak Saragossa'da Bulunan El Yazması'nı gösterir. Todorov'a (2012, s.33) göre bu eserin okuyucunun zihninde uyandırdığı gerçek-düş yanılgısı onun fantastik olarak nitelendirilmesinin en temel nedenidir. Eco (2013, s.161) da Todorov gibi gerçek-hayal arasında okuyucunun düştüğü kuşkuyu fantastiğin temel niteliği olarak görür. Eco'ya göre "romanda bir süre kaldıktan sonra ve haklı olarak fantastik ögelerle gerçekliğe yapılan göndermeleri birbirine karıştırdıktan sonra, okur artık kesin olarak nerede bulunduğunu bilemez" (Eco, 2013, s.161). O, Sherlock Holmes gibi eserlerin başarısının altında yatan etmenin bu durum olduğunu düşünür (Eco, 2013, s.161).

Todorov (2012, s.39), okuyucunun gerçek ile hayal arasında kaldığı kuşku (karasızlık) ögesinin yanında, bu karasızlığın eserdeki kahraman tarafından hissedilmesi ve okuyucunun bu durum karşısında tavır takınması, bir fikir yürütmesi gerektiğini fantastiğin şartları olarak sıralar. Todorov'a göre bu şartları taşımayan eserler fantastik sayılamaz. Moran (2009, s.60), ise Todorov'un bu sinırlamasını dar kapsamlı olarak niteler ve bu nedenle aslında fantastik olan eserlerin bu türden sayılamadığına dikkat çeker. Moran (2009, s.60), bu sebeple türü "genel fantastik, belirsiz fantastik, garip" başlıkları altında inceler.

Fantastik eserler son dönemde okuyucuların ilgi odağında olmaya başlamıştır. Özellikle Batı edebiyatı kaynaklı birçok eser çok satanlar arasında yer almıştır. Bunda Yüzüklerin Efendisi, Hobbit, Harry Potter, Taht Oyunları, Açlık Oyunları gibi eserlerin sinemaya uyarlanması etkili olmuştur. Eserin tanınırlığının artması okuyucu sayısını da doğrudan etkilemiştir.

Türk fantastik edebiyatının gelişimi dünya edebiyatı ile benzerlik gösterir. Uygur metinleri (Altun Yaruk, İyi ve Kötü Prens Öyküsü), Dede Korkut Hikâyeleri ile başlayan fantastik Türk edebiyatının serüveni, Muhayyelat-ı Aziz Efendi ile devam eder. Yonar (2011, s.230) fantastik anlatı türünde Doğu kültürüne ait ögelerin gizli kaldığını, "felsefe taşı" gibi günümüzde 
popüler fantastik eserlerde yer alan ögelerin “Orta Asya sözlü anlatılarının” içerisinde yer aldığını belirtir. Yonar (2011, s.232) Türk edebiyatında fantastik ögeler taşıyan eserlere bakış açısı yönünden Tanzimat döneminin önemli olduğunu ifade eder. Bu dönemde yazarlarda fantastik eserlere yönelik önyargının oluştuğunu belirten araştırmacı, fantastik eserler açısından Tanzimat' 1 "İlk harikulade özelliklerinden dolayı yüz yıl öncesine ait olmasına rağmen Aziz Efendi'nin Muhayyelat'ının yerden yere vurulduğu dönemdir." şeklinde nitelendirir (Yonar, 2011, s. 232-234). Moran (2009, s.59), Muhayyelat-ı Aziz Efendi'yi birçok yönüyle fantastik sayılabilecek ilk eserden biri olarak nitelendirir. II. Meşrutiyet döneminde ise fantastik ögeler eleştirel amaçlı kullanılmaya başlanır. Gündüz (2013, s.20), özellikle Hüseyin Rahmi Gürpınar'ın Gulyabani, Cadı, Mezarından Kalkan Şehit gibi eserlerinde bu durumun açıkça görüldügünü belirtir. Yazar bu eserlerinde batıl inanışları, hurafeleri vb. eleştirerek olayları mantık akışı içerisinde sunar ve sonucu bilimsel bir açıklamaya dayandırır. Son dönem Türk edebiyatında Nazlı Eray (Arzu Sapağında İnecek Var), İhsan Oktay Anar (Suskunlar, Puslu Kıtalar Atlası), Sadık Yemni (Muska), Orkun Uçar (Habis Üçlemesi), Barış Müstecaplığlu (Perg Efsaneleri Serisi) gibi yazarlar fantastik tarzdaki eserleri ile öne çıkmaktadır.

Avangart, yeraltı edebiyatı tarzında eserleri ile tanınmaya başlayan Hikmet Temel Akarsu'nun fantastik ögeleri eserlerine uyarladığı görülmektedir. Özellikle yazarın son dönemde çocuk edebiyatına yönelmesi ve fantastik ögeleri eğitsel amaçlar doğrultusunda kullanması bu alandaki araştırmalara konu olmasını sağlamıştır. Yazarın yayımlanmış on dört romanı, dört öyküsü ve on çocuk hikâyesi bulunmaktadır. Yazarın çocuk hikâyelerinin eğitsel nitelikleri incelendiğinde, değerler eğitimine yönelik olmanın eserlerin önemli özellikleri arasında olduğu belirtilebilir. Bu durum eserlerin değerler eğitimi açısından incelenmesine imkân sağlamaktadır.

Değerler, bireysel ve toplumsal normlar çerçevesinde oluşmaktadır. Bireysel değerler kişilerin karakter özelliklerinin yansıması şeklindedir. Toplumsal değerler ise birlik olabilmeyi, düzen sağlamayı hedeflediği için genel ifadeler şeklinde yer alır. Örneğin sorumluluk, özgüven, dürüstlük gibi değerler daha çok bireysel nitelikler taşırken; hoşgörü, yardımlaşma, barış, millî ve manevi değerler ise toplumun geneline hitap etmeleri ile tanımlanır. Birçok değer sınıflaması bulunmaktadır. Bunların en bilinenlerinden biri Schwartz'ın Değer Listesi'dir. Onun değer listesinde "güç, başarı, hazcılık, uyarılım, evrensellik vb" alanlar yer alır (Kuşdil ve Kağıtçıbaşı, 2000, s.61). Kuşdil ve Kağıtçıbaşı (2000, s.61) Schwatz Değer Listesi'nde bulunan değer alanlarını ve birey güdüsel tipleri şu şekilde ifade ederler:

Tablo 1: Schwartz Değer Listesi'ndeki Değerlerin Birey Güdüsel Tipleri

\begin{tabular}{ll}
\hline Değer Alanı & Değerlerin Açılaması \\
\hline Güç & $\begin{array}{l}\text { Sosyal güç sahibi olmak, otorite sahibi olmak, zengin olmak, } \\
\text { toplumdaki görünümü koruyabilmek }\end{array}$ \\
\hline Başarı & $\begin{array}{l}\text { Başarılı olmak, yetkin olmak, hırslı olmak, sözü geçen biri olmak (zeki } \\
\text { olmak) }\end{array}$ \\
\hline Hazcılık & Zevk, hayattan tat alma \\
\hline Uyarılım & Cesur olmak, değişken bir hayat yaşamak, heyecanlı bir yaşantı sahibi
\end{tabular}




\begin{tabular}{ll}
\hline Öz yönelim & olmak \\
& $\begin{array}{l}\text { Yaratıcı olmak, merak duyabilmek, özgür olmak, kendi amaçlarını } \\
\text { seçebilmek, bağımsız olmak (kendine saygısı olmak) }\end{array}$ \\
\hline Evrenselcilik & $\begin{array}{l}\text { Açık fikirli olmak, erdemli olmak, toplumsal adalet, eşitlik, dünyada } \\
\text { barış istemek, güzelliklerle dolu bir dünya, doğayla bütünlük içinde } \\
\text { olmak, çevreyi korumak (iç uyum) }\end{array}$ \\
\hline İyilikseverlik & $\begin{array}{l}\text { Yardımsever olmak, dürüst olmak, bağ1şlayıcı olmak, sadık olmak, } \\
\text { sorumluluk sahibi olmak (gerçek arkadaşlık, olgun sevgi, manevi bir } \\
\text { hayat, anlamlı bir hayat) }\end{array}$ \\
\hline Geleneksellik & $\begin{array}{l}\text { Alçak gönüllü olmak, geleneklere saygılı olmak, ılımlı olmak (dünya } \\
\text { işlerinden el ayak çekmek) }\end{array}$ \\
\hline Uyma & $\begin{array}{l}\text { Kibarlık, itaatkâr olmak, anne-babaya ve yaşlılara değer vermek, } \\
\text { kendini denetleyebilmek }\end{array}$ \\
\hline Güvenlik & $\begin{array}{l}\text { Ulusal güvenlik, toplumsal düzenin sürmesini istemek, temiz olmak, } \\
\text { aile güvenliği, iyiliğe karşılık vermek (bağlılık duygusu, sağlıklı } \\
\text { olmak) }\end{array}$
\end{tabular}

Kaynak: (Kuşdil ve Kağıtçıbaşı, 2000, s.61; akt. Fidan, 2017, s. 87-88).

Bu değer listesine ek olarak Güven'in (2014, s.508) ise değerleri "sayg1, hoşgörü, yardımlaşma, sorumluluk, barış, ulusal değerler, özgüven vb." şeklinde tanımladığı görülmektedir.

Akarsu'nun eserleri genel olarak fantastik ögeler bakımından incelendiğinde eserlerin çocuklara ve yetişkinlere yönelik olarak iki grupta yer aldığı görülmektedir. Bu gruplandırmada eserlerin içeriksel ve yapısal nitelikleri belirleyici bir konumdadır. Ayrıca sinıflandırmada çocuğa görelilik ilkesinin de göz önünde bulundurulması eserlerin niteliklerinin belirlenmesine yardımcı olmaktadır. Yazarın eserleri genel olarak ele alındığında fantastik ögelerin mitolojik olaylardan, kahramanlardan, mekânlardan yararlanılarak sağlandığı görülmektedir. Bunlara ek olarak eserlerde ruh göçü, yeniden diriliş, fantastik kararsızlık gibi ögelerde yer almaktadır. Çocuğa yönelik fantastik ögeler içeren eserlerde ise kahramanların genel olarak çevre sevgisi, iyilikseverlik gibi belirli değerlerin okuyuculara sezdirilmesi amacını taşıdıkları görülmektedir.

\section{Yöntem}

$\mathrm{Bu}$ araştırmada nitel araştırma yöntemlerinden doküman incelemesi kullanıldı. "Doküman incelemesi, araştırılması hedeflenen olgu veya olgular hakkında bilgi içeren yazılı materyallerin analizini kapsar." (Tanrı̈ğen, 2011, s.239). Araştırmada Hikmet Temel Akarsu'nun çocuğa yönelik eserlerinde yer alan fantastik nitelik taşıyan kahramanların karakter analizleri yapılmıştır. Yazarın çocuğa yönelik olan ve fantastik ögeler taşıyan eserleri araştırma sürecine dâhil edilmiştir. Yazarın çocuğa yönelik fantastik eserlerinin tanımlanmasında araştırmacının "Hikmet Temel Akarsu'nun Fantastik Ögeler ve Eğitim Odaklı Değerler" isimli doktora tezi temel alınmış ve çalışma bu tezden yararlanılarak üretilmiştir. Buradan yola çıkarak yazarın Çevreci Peri, İlham Perisi Türlerin Yok Edilmesine 
Karşı, Uzaylı Peri Dünyamızı Tüketenlere Karşı, Sultan Peri GDO Canavarına Karşı, Güzelçamlı'nın Kayıp Panteri, Birleşmiş Melekler isimli eserlerinde fantastik nitelikleri olan kahramanlar bulunduğu tespit edilmiş ve bu eserler incelenmiştir. Elde edilen veriler betimsel analiz yöntemi ile yorumlanmıştır. Veriler çözümlenirken değerler yani karakter özellikleri ile ilgi yapısal temalandırmalar sonuçların daha uygun bir şekilde yorumlanmasına imkân sağlamıştır. Bu temalandırmada Schwartz'ın Değer Listesi, Güven'in (2014) Değer Listesi, EBA'da yer alan değerler araştırmacı için başvurulan kaynaklardandır.

\section{Bulgular}

Hikmet Temel Akarsu yazarlık hayatının ilk dönemlerinde yetişkinlere yönelik fantastik eserleri ile dikkat çekmiştir. Onun fantastik tarzda kaleme aldığ1 Ölümsüz Antikite serisi üç eserden oluşmaktadır. Yazar bu seriye bir eser daha eklemek istemiş ancak daha sonra bu isteğinden vazgeçtiğini belirtmiştir. İlgili eserlerde Akarsu, Yunan mitolojisinden uyarlamalar yaparak modern bir tragedya oluşturmaya çalışmıştır. Eserde Euripides'in ünlü İlyada destanındaki olayların, kahramanların, mekânların günümüze uyarlanmış biçimleri bulunmaktadır. Yazarın buradaki yaptığı uyarlamaların temel çıkış noktası "Olimpos" ile "Silikon Vadisi'nin" birbirinin mirasçısı olma özelliği göstermesidir. Nitekim kahramanlar da sadece isim yönüyle değil karakter özellikleri bakımından da mitolojik atalarına benzer. Bu yönüyle yazarın eserinde fantastik bir yöntem olan "yeniden diriliş" ögesini kullandığ 1 görülür.

Yazarın yoğun olmasada fantastik ögeler kullandığı bir başka seri eseri ise Kayıp Kuşak başlığı altında toplanır. İlgili eserde yaşadığ1 olaylar sebebiyle topluma küsmüş, yabancılaşmış bireyler ve hayatın düzenine ayak uydurup bütün insani değerlerden soyutlanan karakterler yer alır. İstanbul Dörtlüsü başlığ1 altında toplanan eserde de içinde yaşadığı topluma yabancılaşmış bireyler yer alır. Ayrıca bu eserde Batı ve güç hayranı olduğu simgelenen diğer bireylerin içinde yaşadıkları topluma yabancılaşmalarında çevrelerindeki insanları değersiz, küçük görmeleri yatar. Kendilerini beğenmiş yapıları onların mensubu bulundukları toplumdan uzaklaştırır. Yazar da bu farklılaşmaları DoğuBatı çatışması ekseninde kurgular.

Akarsu'nun tarihi roman niteliği taşıyan Özgürlerin Kaderi ve Konstantinopolis Kapılarında isimli eserlerinde fantastik ögeler dini bir yapı içerisinde sunulur. Eserin ana kahramanı olan "Bilge Dede" gösterdiği kerametlerle obasının ve milletinin geleceğine etki eder. Diğer kahramanlarda görülmeyen bu fantastik etki “Bilge Dede'nin” karakteristik özelliği olarak eserde öne çıkar.

Yazarın Nihilist isimli eseri tamamen fantastik ögeler taşır. Kendisini "Kaybedenlerin Mesihi" olarak tanımlayan kahraman vasıtasıyla fantastik öge de kullanılarak modern çağın en temel problemlerinden olan özel manada kendisine yabancılaşmış genelde ise topluma yabancılaşmış, uyumsuz bireyler anlatılır.

Yazarın çocuklara yönelik eserleri incelendiğinde on kitabının olduğu görülür. Yazarın çocuğa yönelik eserinde ana tema genel olarak doğa sevgisidir. Benzer şekilde çocuksu fantastik eserlerinde de fantastik öge çevre bilinci oluşturabilmek için kullanılır. Eserlerde 
çevrede yaşanan olumsuz durumlar fantastik bir olay yada fantastik bir kahraman vasıtasıyla çözülür. Araştırma sırasında yazarın bu eserlerinin altısında fantastik ögeler tespit edilmiştir. Yazarın çocuğa yönelik eserleri arasında fantastik öge taşıyanlar şu şekilde siralanabilir:

Çevreci Peri, İham Perisi Türlerin Yok Edilmesine Karşı, Uzaylı Peri Dünyamızı Tüketenlere Karşı, Sultan Peri GDO Canavarına Karşı, Güzelçamlı'nın Kayıp Panteri, Birleşmiş Melekler.

Eserlerdeki olaylardan yola çıılarak kahramanların karakter özellikleri ve bu özellikleri karşılayan değer alanlarının bulunduğu tablo aşağıda yer almaktadır:

Tablo2: Kahramanlar ve değer alanları

\begin{tabular}{lll}
\hline Değer alanı & Yer aldığı eser & Değerle bağdaşan kahraman \\
\hline $\begin{array}{l}\text { Doğruluk- } \\
\text { Dürüstlük }\end{array}$ & Çevreci Peri & $\begin{array}{l}\text { Çevreci peri (Örnek davranış) } \\
\text { Siyah Peri (Örnek davranış) }\end{array}$ \\
\hline & Siyah Peri (Örnek davranış) \\
& & Mavi Peri (Örnek davranış) \\
& & Kar Perisi (Örnek davranış) \\
& & Deniz Kızı (Örnek davranış) \\
\cline { 2 - 3 } & $\begin{array}{l}\text { İlham Perisi: } \\
\text { Türlerin Yok }\end{array}$ & Sivrisinekler, Tuna, Atoş, Lokman Hekim, \\
& $\begin{array}{l}\text { Edilmesine } \\
\text { Karşı }\end{array}$ & Flamingo (Örnek davranış) \\
\cline { 2 - 3 } $\begin{array}{ll}\text { Doğa-çevre } \\
\text { sevgisi }\end{array}$ & $\begin{array}{l}\text { Birleşmiş } \\
\text { Melekler }\end{array}$ & Kent Perisi (Örnek davranış) \\
\cline { 2 - 3 } & &
\end{tabular}

Kargalar (Örnek davranış)

Sultan Peri

GDO GDO'lu gidalarla beslenen hayvanlar (eleştirel

Canavarına yaklaşım)

Karşı

Güzelçamlı'nın

Kayıp Panteri Güzelçamlı'nın Kayıp Panteri (Örnek davranış)

Çevreci Peri Çevreci peri (Örnek davranış)

İyilikseverlik

Siyah Peri (Örnek davranış) 
Birleşmiş

Melekler

Kent Perisi (Örnek davranış)

Uzaylı Peri

Dünyamızı

Tüketenlere

Dilek perisi (Örnek davranış)

Karş1

Uzaylı peri (Örnek davranış)

Güzelçamlı'nın

Kayıp Panteri

Güzelçamlı'nın Kayıp Panteri (Örnek davranış)

Akarsu'nun fantastik ögeler taşıyan ve çocuğa yönelik olan ilk eseri Çevreci Peri'dir. Bu eserin anlatıcısı da olan Çevreci Peri ana kahraman olarak okuyucuya sunulur. Kahramanın adını verdiği eserde insanlara yardım eden periler ve onların eğitim gördüğü peri okulunda yaşanan olaylar anlatılır. Serinin diğer eserlerinde bu okuldan bahsedilmemesine rağmen kurgusal yönden bakıldığında okuyucuda böyle bir izlenimin oluşturmaya çalışıldığ 1 görülür. Zira diğer eserlerin genelinde de benzer karakterlerdeki periler dünyaya dönerek insanlara, doğaya yardım eder. Yazarın ilgili eserlerindeki kahramanların en belirgin karakter özellikleri şu şekilde sıralanabilir:

\section{Doğruluk- Dürüstlük}

"Doğruluk" eğitim programlarının öğrencilere kazandırmaya çalıştıkları en önemli değerlerin başında gelir. Doğruluk, hem bireysel hem de toplumsal manada güvenin sağlanmasında etkili bir konumda bulunur. Değerlerin çocukluk döneminde kazanıldığı ve benimsendiği düşünüldüğünde bu yaş grubundaki çocuklarda değerin benimsetilmesinde kullanılan eğitsel materyaller önem taşır. Hikâyeler, romanlar, masallar gibi yazılı metinler özelde Türkçe dersinde genelde ise bütün derslerde hem anlama-idrak hem de kendini ifade edebilme becerilerine olumlu katkısından dolayı kullanılmaktadır. Bu eserlerin eğitsel nitelik taşıması ilk aranan özelliklerdendir. Eserlerin dil anlatım yönünden öğrencilere uygunluğunun yanı sıra, değerler sistemi açısından da öğrencilere uygun olması gerekir. Eserlerde yazarlar tarafından yüceltilen, örnek gösterilen kahramanlar kişilik özellikleri açısından da öğrenciye uygun olmalıdır. Çünkü eserlerdeki kahramanların davranışları, öğrenciler tarafından içselleştirilmektedir. Onların sergileyecekleri olumlu davranışlar ilgili yaştaki okuyucunun da aynı yönde duygusal olarak etkilenmesine olanak sağlamaktadır.

Todorov'a göre (2012, s.39), fantastiğin en önemli özelliği okuyucunun zihninde hayalhakikat kararsızlığı uyandırmasıdır. Buna göre okuyucunun zihninde bu kararsızlık uyandığ1 müddetçe okuyucu fantastiğin etkileyici dünyasına girmiş olur. Aksi takdirde fantastik eserin masaldan farkı kalmaz. Bu düşünceyi oluşturabilmek için eserde yazar, perilerle ilgili düşüncelerini gerçekçi bir zemine dayandırmaya çalışır. İlk olarak okuyucunun zihninde gerçeklik algısı oluşturmayı amaçlar. Eserde perilerin dürüst 
oldukları, asla yalan söylemedikleri sıklıkla belirtilir. Çevreci Peri'nin “Anlatacaklarım o kadar ilginç ki gerçek olduklarına inanmayacaksın. Çocukluğunuzdaki peri masallarından birini dinlediğinizi sanacaksın. Ama bunlar yaşandı..." (Akarsu, 2010, s.59) şeklindeki sözleriyle okuyucuda esere dair gerçeklik algısı oluşturulmaya ve eserin dürüstlük ekseninde temalandırılmaya çalışıldığı görülür. Çünkü eserde fantastik karakterlerden olan Çevreci Peri, okuyucularını masallardan aşina oldukları perilerden farklı olduğuna inandırmaya, yani kendisinin gerçek bir varlık olduğuna ikna etmeye çalışır. Anlatıcı eserinde gerçeklik algısının sağlanması görevini bu çerçevede Çevreyi Peri'ye yükler. Onun eser boyunca sergilediği dürüst karakter örneği, okuyucu açısından eserin inandırıcılığına etki etmektedir. Çünkü esere yönelik gerçeklik algısının oluşturulabilmesi için kahramanın da okuyucu tarafından benimsenmesi gerekmektedir.

Eserde periler insanlar için iyilik yapma yarışındadır. Anlatıcı, okuyucunun zihnindeki peri imajını değiştirmek için kahramanlarını dürüstlük yönüyle ön plana çıkarır. Çevreci Peri'nin “Oysa bizim peri okulunda başardıklarımız her zaman inanılması çok güç işlerdir. $\mathrm{O}$ yüzden, insanlar bizi hep birer yalancı olarak görürler. Devamlı yalan söylediğimizi sanırlar." (Akarsu, 2010, s.7) ifadesinde de görüldüğü üzere kahraman, kendilerine karşı ön yargılı davranılmasından şikâyetçidir. Aslında kendilerinin sanılanın aksine dürüst olduklarını belirtir. "O insanlar, perilerin sadece bir efsaneden ibaret olduğunu iddia ederler."(Akarsu, 2010, s.8) ifadesinde de görüldüğü üzere insanlardaki ön yargının kırılması periler için çok zorlu bir görevdir. Eserde periler okulunun temel düsturunun doğrulukdürüstlük olduğu belirtilir. Okuldaki perilerin Siyah Peri'ye yönelik "Bir peri asla yalan söylememelidir." (Akarsu, 2010, s.8), "Ne garip! Bir perinin yalan söylemesi ne ayıp." (Akarsu, 2010, s.10) şeklindeki ifadeleri okulun eğitim sistemini açıklaması açısından önem taşır. Okuldaki perilerin Siyah Peri hakkındaki ön yargılı düşünceleri onların gerçekleri öğrenmeleriyle değişime uğrar. Bu konuda yanılgıya düştüklerini belirterek Siyah Peri'yi yüceltmeye çalışırlar (Akarsu, 2010, s.19).

Anlatıcının eserde dürüstlük değerini ön plana çıarmasında hem eserin fantastik yapısını kuvvetlendirme hem de örnek davranışlar sergileyen kahramanların sahip oldukları özellikleri okuyucuya sezdirme düşüncesi yatar. Anlatıcının dürüstlüğü kahramanların karakter özelliği olarak sunması eserin değerler eğitimi açısından önemini artırmaktadır.

\section{Doğa-Çevre Sevgisi}

Doğa sevgisi bir değer olmasının yanında Akarsu'nun çocuğa yönelik eserlerinde kahramanların davranışlarına sirayet etmiş ve kahramanlar tarafından içselleştirilmiş bir değerdir. Anlatıcı bu şekilde doğa sevgisi konusunda çocuk okuyucuda farkındalık uyandırmayı amaçlamaktadır. Yazarın Güzelçamlı'nın Kayıp Panteri isimli eserinde doğanın korunmasında üstlendiği görev ile Kayıp Panter, insanların yangına karşı büyük başarı elde etmelerine vesile olur. İlham Perisi isimli eserde küçük bir çocuk olan Tuna, çevre konusunda büyüklerinden daha duyarlı bir karakterdedir. Tuna, babasına “Doğada görevi bulunmayan hiçbir canlının olmadığını" söyleyerek bu konuda onda bilinç oluşturmaya çalışır (Akarsu, 2013, s.21). Eserde Tuna'nın doğayı sevmesinde etkili olan durum fantastik bir temele dayandırılır. Tuna'nın yaşadığı fantastik olaylar onun doğayı sevmesinde etkili olur. Onun 
geceleri odasına dolup “hepsi şarkı söyleyen” sivrisinekler, Tuna'ya doğayı sevmeyi öğretmişlerdir (Akarsu, 2013, s.28).

Aynı eserin Flamingo adlı öyküsünde ise Tuna dünyayı terk eden arıları bulmak için yola çıkar. Çünkü eğer arılar yok olursa yaşam da yok olacaktır. Bu amaçla Tuna, Lokman Hekim'e kadar uzanan fantastik bir maceraya atılır. Lokman Hekim buradaki arıları "bir flamingo kadar uçucu, zarif, hayalci ve iyi kalpli birinin götüreceğini" söyleyerek Tuna'yı sevgiyle karşılar (Akarsu, 2013, s.50). Ayrıca burada Atoş karakterinin de doğa sevgisi çerçevesinde Tuna'ya yardım ettiği görülür.

Kent Perisi isimli öyküde peri, plansız kentleşmeden dolayı çocukların maruz kaldıkları tehlikeye dikkat çeker. Zor durumlarında çocukların yardımına koşan Kent Perisi'ne yazar önemli bir sorumluluk yükler. Çünkü onun yardım ettiği çocuklarla eseri okuyan çocuklar benzer yaş grubundadırlar. Bu durum çocuğun empati yapmasını sağlayarak değerleri içselleştirmesini kolaylaştırmaktadır. Yazar bu vasıtayla okuyucuda çevre konusunda farkındalık oluşturmayı amaçlar. Yazarın Bozdoğan Kemeri isimli öyküsünde "Kargalar yaşam alanlarını ve tarihi korurlar." (Akarsu, 2015, s.186). Yazarın hayalî ögeleri gerçek yaşamın içine yerleştirmesi eserin fantastik yapının güçlenmesine katkı sağlamaktadır.

Çevreci Peri isimli eserde yer alan bir diğer fantastik özellikler taşıyan kahraman Mavi Peri'dir. Onun kişilik özellikleri incelendiğinde canlıların doğa ile uyum içerisinde yaşamalarını arzu ettiği görülmektedir (Akarsu, 2010, s.43). Bu özellikler Mavi Peri'nin değerler eğitimi açısından doğa sevgisi değeri alanı içerisinde davranışlar sergilediğini göstermektedir. Çevreci Peri'de yer alan Kar Perisi karakterinin de eserin ismi ile bağlantılı olarak çevre-doğa sevgisi doğrultusunda davranışlarının olduğu görülmektedir. Onun aşırı plastik kullanımına ve bu plastik atıkların çevreye verdiği zararlara dikkat çekmesi, ayrıca bu özellikleri ile insanlara örnek olması (Akarsu, 2010, s.67) eserde takdir edilecek bir davranış olarak sunulmaktadır. Çevreci Peri isimli eserde yer alan öykülerde geçen bir diğer fantastik kahraman denizkızıdır (Mermaid). Eserde anlatıcının denizlerin kirletilmesini, denizkızının yaşamı boyunca başına gelen felaketlerin sebebi olarak gösterdiği görülmektedir. Ayrıca bu durumun küresel bir sorun niteliğinde olduğu da eserde vurgulanmaktadir (Akarsu, 2010, s.79).

\section{İyilikseverlik}

Yazarın çocuklara yönelik fantastik ögeler taşıyan eserleri incelendiğinde iyilikseverlik değerine de özel önem verildiği görülebilmektedir. Bu doğrultuda Çevreci Peri isimli eser ele alındığında peri okulunda eğitim gören perilerin önemli amaçları arasında insanlara iyilik yapabilme, yardım edebilme yer almaktadır. Çevreci Peri'nin “İyilik yapmayı bitirdiğimizde de "Pırrr!" diye uçar, ortadan kayboluruz." (Akarsu, 2010, s. 7) ifadesinde de bu durum gözlemlenebilmektedir. Eserde diğer periler gibi Siyah Peri vasıtasıyla da insanlara, doğaya yardım etmek yüceltilmiş bir değer olarak sunulur. Çevreci Peri'nin hakkındaki şu ifadeler onların iyiliksever özelliklerinin göstergesi niteliğindedir: 
“Ama bu inanılmaz bir yanılgı çocuklar. Çevreci Peri okulumuzdaki bütün periler gibi çok dürüst, yaratıcı ve kahraman bir çocuktur. İnanılması güç şeyler başarmış, dünyadaki bütün canlılara sayamayacağım kadar çok iyilik yapmıştır." (Akarsu, 2010, s. 19).

Uzaylı Peri Dünyamızı Tüketenlere Karşı isimli eserde Dilek Perisi çocuğa, hayvanlara karşı merhametli davranışından dolayı hediye olarak üç dilek dileme hakkı sunar (Akarsu, 2013, s.19). Ancak peri, çocuğun bütün dileklerini reddederek emeğe dikkat çekmeye çalışır. Eserde Dilek Perisinin davranışları ile insanlara yardımcı olmaya çalıştığı görülmektedir. Çevre sevgisinin yanında iyiliksever de olan bu kahraman, kedi yavrularına süt veren Fikret'e dilek hakkı vererek ona yardımcı olmaya çalışır. Dilek Perisi, "araba insanı tembelleştirir, tembelleşen insan şişmanlar, sağlığı bozulur, sonra araba insanı spordan uzaklaştırır. Kolaycılığa alıştırır." (Akarsu, 2013, s.20) gibi telkinlerle Fikret'e yönlendirmede bulunur. Ayrıca bu öykü vasıtasıyla çalışmanın önemi, hak edebilme, çevre bilinci gibi kavramlara da vurgu yapıldığı görülmektedir (Fidan, 2017, s.171). Anlatıcı bu vasıtayla çevre sevgisinden yola çıkarak merhamet duygusunu ön plana çıarır. Çünkü eserde kişisel olarak faydalı gibi görünen dilekler aslında diğer canlılara zarar vermektedir.

Bir diğer fantastik kahraman olan Kent Perisi'nin şehirdeki çocukları tehlikelerden koruması onun iyilikseverlik özelliğinden kaynaklanır. $\mathrm{O}$, çocukları kendi anne babalarından daha çok düşünerek bu konuda okuyucuda farkındalık oluşturmaya çalışır. Sultan Perisi isimli öyküde anlatıcı, perilerin yardımları vasıtasıyla GDO'lu gıdaların zararlarına dikkat çekmeye çalışır. Yazar fantastik unsurları kullanarak hayvanların bu gıdalarla beslenmesi sonucu uğradıkları mutasyonu okuyucuya fantastik bir şekilde sunar: "Hayır; rüyada değildi..." (Akarsu, 2013, s.63).

Güzelçamlı'nın Kayıp Panteri isimli eserde panterin çıkardığı yönlendirici sesler orman yangının söndürülmesinde insanlara büyük fayda sağlar. Bu durum panterin çevre sevgisi değerinin yanında, yardımseverlik yönünün de olduğunu göstermektedir. Yazarın bu değere eserlerinde yer vermesi toplumsal açıdan önem taşır. Çünkü toplumu bir arada tutan değerlerden biri yardımseverlik, iyilikseverliktir. Bu davranış insanlar arasındaki bağları güçlendirerek ekonomik, fiziksel, ruhsal vb. yönlerden dezavantajlı bireylerin toplumla uyum içinde yaşamasına yardımcı olmaktadır.

\section{Tartışma ve Sonuç}

Hikmet Temel Akarsu'nun çocuğa yönelik eserlerinde yer alan fantastik kahramanları Çevreci Peri, Siyah Peri, Dilek Perisi, Tuna, Lokman Hekim, Kent Perisi, Güzelçamlı'nın Kayıp Panteri, kargalar, sivrisinekler, GDO'lu besinler sebebiyle mutasyona uğramış hayvanlar vb. şeklinde sıralamak mümkündür. Burada mutasyona uğramış hayvanlar dışında yer alan diğer fantastik karakterlerin özellikleri incelendiğinde bunların üç temel değerde toplandıkları sonucuna ulaşılmıştır. Bu değerler doğruluk, çevrecilik-doğa sevgisi, iyilikseverliktir. Yazarın çocuğa yönelik fantastik eserlerinde yer alan kahramanların kişilik özelliklerinde genel olarak bu üç temel değerin yer aldığ görülmektedir. 
Değerlerin öğretiminde ve bireyler tarafından içselleştirilmesinde kitaplar önemli konumda bulunmaktadır. Özellikle çocuklara yönelik eserler, sundukları hayal dünyası ve örnek kahramanlar vasıtasıyla bu konuda etkili olabilmektedir. Bu doğrultuda yazarların çeşitli değer alanları ile özleşmiş kahramanları eserlerinde kullandıkları görülmektedir. Araştırmamıza konu olan eserlerde yazarın fantastik nitelikler taşıyan kahramanları iyilikseverlik, çevre sevgisi gibi değerleri anlatabilmek için kullandığı tespit edilmiştir. Kahramanlara fantastik nitelikler kazandırılmasının, onları çocuk okuyucular için daha ilgi çekici kılma amacından kaynaklandığı düşünülmektedir. Bu konudaki araştırmalar incelendiğinde ilgi çekicilik özelliği dolayısıyla hayvan karakterlerin de değerlerin aktarımında kullanıldığı görülmektedir. Örneğin, Yılmaz (2016, s.323) araştırmasında hayvan karakterlerin değerlerin çocuklara aktarımında kullanıldığını belirtmektedir. $\mathrm{Bu}$ alanda ilgili yapılan bazı araştırmalar incelendiğinde yazarların eserlerinde benzer değerleri işledikleri görülebilmektedir. Sallabaş'ın (2012, s.59) Ömer Seyfettin'in eserlerine yönelik araştırması incelendiğinde, tespit edilen değerler arasında çalışmamızın sonuçları ile benzerlikler taşıyan "adil olma, yardımseverlik, dayanışma" değerlerinin de yer aldığı görülmektedir. Erol'un (2014, s.177) Tarık Buğra'nın eserlerini değerler eğitimi bağlamında incelediği araştırmasında tespit ettiği değerlerden olan "dürüst olma, doğayı sevme" bu çalışmada yer alan değerlerle benzerlik taşımaktadır. Sema Maraşlı'nın eserlerini inceleyen Topbaş'ın (2015, s.107) araştırmasında tespit ettiği değerler arasında da "dayanışma, dürüstlük, yardımseverlik" gibi değerler yer almaktadır. Memduh Şevket Esendal'ın hikâyelerine yönelik çalışmasında Esen'in (2016, s.427) tespit ettiği değerler arasında yer alan "doğa ve hayvan sevgisi, yardımseverlik, doğruluk-dürüstlük" gibi değerlerin de bu çalışmanın sonuçları ile benzerlik taşıdığı söylenebilir. Bu sonuçlar özellikle çocuk edebiyatı yazarlarının eserlerindeki kahramanları vasıtası ile işledikleri değerlerin genel olarak benzerlik taşıdığını göstermesi açısından önemlidir.

Araştırmada yazarın fantastik özellikleri olan kahramanlarının bu davranışları vasıtası ile okuyucuda farkındalık oluşturmaya çalıştığı görülmüştür. Ayrıca eserlerde fantastik kahramanların çocuksu nitelikler taşımaları, çocuk okuyucuların onlarla empati kurmalarını kolaylaştırmakta ve çocukların değerleri içselleştirmelerine imkân sağlamaktadır. Bu eserlerde kullanılan eğitsel değerlerin onların eğitim materyali olarak kullanılmasına zemin oluşturacağı araştırmacı tarafından düşünülmektedir. Fantastik ögelerin çocuklar üzerindeki merak uyandırıcı niteliğinden dolayı ilgili eserlerin eğitsel metinlerde kullanılabileceği düşünülmektedir.

\section{Kaynakça}

Akarsu, H. T. (2010). Çevreci peri: doğa düşmanlarına karşı. İstanbul: Çizmeli Kedi Yayınları.

Akarsu, H. T. (2013). Güzelçamlı'nın kayıp panteri. (4.Basım). İstanbul: Can Çocuk Yayınları.

Akarsu, H. T. (2013). İlham perisi: türlerin yok edilmesine karşı. (2. Basım). İstanbul: Çizmeli Kedi Yayınları.

Akarsu, H. T. (2013). Sultan peri: gdo canavarlarına karşı. İstanbul: Çizmeli Kedi Yayınları.

Akarsu, H. T. (2013). Uzaylı peri dünyamızı tüketenlere karşı. (2. Basım). İstanbul: Çizmeli Kedi Yayınları. 
Akarsu, H. T. (2015). Birleşmiş melekler. İstanbul: Çizmeli Kedi Yayınları.

Eba. (2017). Değerler eğitimi. https://www.eba.gov.tr.

Eco, U. (2013). Anlatı ormanında altı gezinti (çev. K. Atakay). İstanbul: Can Yayınları.

Erol, E. E. (2014). Tarık Buğra'nın hikâyelerinin değerler eğitimi açısından incelenmesi. (Yayımlanmamış yüksek lisans tezi). Yüzüncü Yıl Üniversitesi Eğitim Bilimleri Enstitüsü, Van.

Esen, Ş. (2016). Memduh Şevket Esendal'ın hikâyelerinin söz varlığı ve değerler eğitimi açısından incelenmesi. (Yayımlanmamış yüksek lisans tezi). İnönü Üniversitesi Eğitim Bilimleri Enstitüsü, Malatya.

Fidan, M. (2017). Hikmet Temel Akarsu'nun eserlerindeki fantastik ögeler ve eğitim odaklı değerler. (Yayımlanmamış doktora tezi). Atatürk Üniversitesi Eğitim Bilimleri Enstitüsü, Erzurum.

Gündüz, O. (2013). Cumhuriyet dönemi Türk romanı. Ramazan Korkmaz. (ed.). Yeni Türk Edebiyatı El Kitabı (1839 - 2000) içinde (s. 399-574). Ankara: Grafiker Yayınları.

Güven, A. Z. (2014). Gülistan ve Bostan adlı eserlerin değerler eğitimi bakımından incelenmesi. Turkish Studies, 9 (6), 505-517.

Kuşdil, M. E., Kağıtçıbaşı, Ç. (2000). Türk öğretmenlerin değer yönelimleri Schwartz'ın değer kuramı. Türk Psikoloji Dergisi, 15 (45), 59-76.

Korkmaz, R. (2013). Yeni Türk edebiyatına giriş. Ramazan Korkmaz. (ed.). Yeni Türk Edebiyatı El Kitabı (1839 - 2000) içinde (s. 13-42). Ankara: Grafiker Yayınları.

Moran, B. (2009). Türk romanına eleştirel bir bakış 3. İstanbul: İletişim Yayınları.

Özlük, N. (2011). Türk edebiyatında fantastik roman. İstanbul: Hiperlink Yayınları.

Sallabaş, M.E. (2012). Ömer Seyfettin hikâyelerinin Türkçe öğretiminde değer aktarımı bakımından incelenmesi. Mustafa Kemal Üniversitesi Sosyal Bilimler Enstitüsü Dergisi, 9(18), 59-68.

Tanpınar, A.H. (2013). On dokuzuncu asır Türk edebiyatı tarihi (21. Baskı). İstanbul: Dergâh Yayınları.

Tanrı̈gen, A. (2011). Bilimsel araştırma yöntemleri. Ankara: Anı Yayınları.

Todorov, T. (2012). Fantastik - edeb̂̂ türe yapısal bir yaklaşım. (2.Basım). İstanbul: Metis Yayınları.

Topbaş, A. (2015). Sema Maraşlı'nın masallarının değerler eğitimi açısından incelenmesi. (Yayımlanmamış yüksek lisans tezi). Necmettin Erbakan Üniversitesi Eğitim Bilimleri Enstitüsü, Konya.

Yılmaz, O. (2016). Kurgusal nitelikli çocuk kitapları ve karakter eğitimi. Ana Dili Eğitimi Dergisi, 4(3), 311-325.

Yonar, G. (2011). Türk edebiyatında fantastiğin kökenleri: harikulade ve olağandışı. Ankara: Ötüken Neşriyat. 